\begin{abstract}
Iranica
Abstracta Iranica Revue bibliographique pour le domaine irano-aryen

Volume 42-43 | 2021

Comptes rendus des publications de 2019-2020
\end{abstract}

\title{
Yann Richard, « Ali Shariati et la quête du divin »
}

\section{Denise Aigle}

\section{OpenEdition}

Journals

Édition électronique

URL : https://journals.openedition.org/abstractairanica/52739

DOI : 10.4000/abstractairanica.52739

ISSN : 1961-960X

Éditeur :

CNRS (UMR 7528 Mondes iraniens et indiens), Éditions de l'IFRI

Référence électronique

Denise Aigle, «Yann Richard, « Ali Shariati et la quête du divin » », Abstracta Iranica [En ligne], Volume 42-43 | 2021, document 2, mis en ligne le 15 avril 2021, consulté le 13 décembre 2022. URL : http:// journals.openedition.org/abstractairanica/52739; DOI : https://doi.org/10.4000/abstractairanica. 52739

Ce document a été généré automatiquement le 13 décembre 2022.

Tous droits réservés 


\title{
Yann Richard, « Ali Shariati et la quête du divin »
}

\author{
Denise Aigle
}

\section{RÉFÉRENCE}

Yann Richard, «Ali Shariati et la quête du divin », Mélanges de l'Institut dominicain d'études orientales, vol. 35, 2020 (Dossier - Les interactions entre (šĩitites imāmites et chrétiens), p. 197-214.

1 La vie de Ali Shariati, considéré comme l'un des idéologues de la révolution iranienne, est bien connue mais une partie de son parcours intellectuel demeure encore partiellement mystérieux. Y. Richard s'intéresse ici à l'une de ces zones d'ombre en reprenant le dossier des relations entre Ali Shariati et Massignon. Celui-ci aurait inspiré l'intérêt du penseur iranien pour le christianisme. Y. Richard traduit quelques extraits de différentes œuvres peu connues de Ali Shariati. Tout d'abord un passage de ses "écrits du désert " sur une forme d'initiation inspiratrice où se rencontrent bouddhisme, mithraïsme, Massignon et Ḥāfiz (p. 204-206). Il traduit également la thématique de l'Annonciation dans Les causeries de la solitude, où Marie occupe un rôle central (p. 206-207). Il traduit également le chant de la création, présenté comme un poème, qui reprend le début de l'Évangile de Jean (p. 208-209). Et enfin une évocation mystique de la Terre céleste (p. 209-210) qui se termine par une «surprenante divination de 'Alī», selon Y. Richard, qui conclut que Ali Shariati est toujours resté chiite. 


\section{AUTEURS}

DENISE AIGLE

UMR 8167 - Orient et Méditerranée 